European Journal of Business and Innovation Research

Vol.8, No.5, pp 80-96, August 2020

Published by ECRTD-UK

Print ISSN: 2053-4019(Print), Online ISSN: 2053-4027(Online)

\title{
Understanding the Nexus between Electronic Service Performance and Customer Satisfaction among Online Shoppers in a Typical Emerging Economy
}

\author{
Esiti, Blankson Governor \\ Department of Petroleum Marketing and Business Studies \\ Petroleum Training Institute, Effurun, Nigeria. \\ \& \\ Esiri, Kesiena Henry \\ Department of Petroleum Marketing and Business Studies \\ Petroleum Training Institute, Effurun, Nigeria.
}

\begin{abstract}
The main objective of this study is to empirically investigate the influence of electronic service performance on customer satisfaction among online retail customers in Anambra State, Nigeria. The development of information and communication technology (ICT) and its wide application to business especially retailing led to the development of alternative methods of distributing goods and service hence, the emergence of many online retail shops that are challenging the traditional methods of retailing. In view of this and in view of the fact that customers are keying into this emergent phenomenon, customer satisfaction with the online retail shops is imperative. Hence this study set out to examine service performance and customer satisfaction among online retail shoppers in Nigeria. The study was based on a survey of 288 online shoppers in Anambra State. The data collected were analysed with multiple regressions and the outcome was useful to online shoppers, online retailers among others.
\end{abstract}

KEYWORDS: Service Performance, Customer Satisfaction, Online Shoppers, Emerging Economy, Nigeria.

\section{INTRODUCTION}

The use of the Internet is no longer limited to those computer nerds who do it for fun or curiosity. It has opened up tremendous business opportunities for its users especially in the area of retailing business through the electronic commerce platforms. The development of e-commerce is at an unprecedented rate that permeates all aspects of society, which has significant impacts in retail business. As an information technology application in the area of retailing, e-commerce or online retailing is profoundly changing the traditional way of marketing, production as well as management of existing services and consumption patterns. E-commerce represents the future direction of development of retail business; the market has a great potential and a broad development prospect.

The service industry and in particular, the retail market has been vital to the world economy and undergone the ever-intensified competition under recent crisis and economic turn-down period. The modern retail industry is booming across the world. Hence retailers are using strategies which focus on satisfying current customers. With the improvement of living standards and accelerating pace of life, consumers' shopping behaviour has changed greatly. E-commerce represented by the network economy is changing the way people live. In the case of Nigeria, online retail business has come to stay, and it is growing at an increasing rate (World Internet Stats, 2017). This is evident by the rapid growth witnessed in the industry due to the influx of 
many e-commerce giants having operational bases in Nigeria like ebay, Aliexpress, Alibaba, Amazon; and, there are numerous indigenous e-commerce firms like Jumia, Yudala, Adibba, Payporte etc. This connotes that online retailing is not novel in Nigeria anymore.

Customer satisfaction has become a critical issue in the success of every business system, traditional or the cyber shopping store. Satisfaction is a consumer's post-purchase evaluation, effective and affective response to the overall product or service experience (Adjei \& Denanyoh, 2014). It is considered a strong predictor for behavioural variables such as repurchase intentions, word-of-mouth recommendations, or loyalty (Adjei \& Denanyoh, 2014). In the word of Khurshid (2013) customer satisfaction means how much the present customers are happy and motivated from the company. He further states that it is considered very important for companies that their customers are loyal to them because if they are happy it will help the firm to build long term relationship with the customers so that they can purchase more and more from them and also recommend it to other customers as well. More so, customer satisfaction is a dynamic and relative concept. Today's customer satisfaction is not satisfied with respect to terms of yesterday, and does not mean that tomorrow any retailer is assured of satisfaction from customers (Rahman \& Han, 2011).

Furthermore, the development of online shopping activities which is replacing the traditional way of shopping has led to a fundamental change in the status of the consumer and made a fundamental shift, from the previous passive to active consumer status. Therefore, in the Internet time, compared to traditional retailing, service performance to satisfy customers and to cultivate customers' loyalty for online shopping is much more important. In addition, the current consumer online shopping satisfaction and trust is not high. An online consumer survey in North American (2006), reported that $34 \%$ of shoppers see online customer service unsatisfactory. Internet users trust the Internet less, only one third (35.1\%) of Internet users said that they trusted in the Internet. Using the above stated facts as the point of departure, it could be the case of Nigerian online retail customers; because it has been observed that the majority of e-commerce customers in Nigeria may not be satisfied with the services provided by most e-commerce service providers, this is evident by incessant complaints and high rate of switching to different e-commerce firms in order to get satisfaction.

Furthermore, while developing a reference model for summarizing the antecedents of customer satisfaction from research studies on online shopping, Chang et al. (2005) categorized the antecedents into three categories namely, perceived characteristics of the web as a sales channel, web site and product characteristics and consumer characteristics, thus identifying more than 80 variables as determinants. Chang et al., failed to further their study by investigating the nexus between the identified predictors of service performance and customer satisfaction in the online retail industry.

Although numerous studies have been conducted on service performance in the online retail industry in the extant literature (Chang et al.; 2005, Chen, Chang, Hsu \& Yang, 2011; Wirtz, 2003; Wirtz \& Mattila, 2001; Karmakar, 2004; Coye 2004; Rahman \& Han, 2011). None of these studies investigates the nexus between service performance and customer satisfaction. Moreover, these studies were conducted in America, Europe and Asia; as such they cannot represent the interest of online retail customers in a typical sub-Saharan Africa like Nigeria. It is therefore necessary and expedient to conduct an empirical study that investigates the nexus between 
service performance and customer satisfaction and; to conduct a context-specific study that can be generalized in Sub-Saharan Africa. The broad objective of this study is to empirically investigate the influence of service performance on customer satisfaction among online retail customers in Anambra State. Specifically, this study will seek to:

(a) Determine the influence of system efficiency on customer satisfaction in the Nigerian online retail industry.

(b) Ascertain the influence of system availability on customer satisfaction in the Nigerian online retail industry.

(c) Examine the influence of fulfilment on customer satisfaction in the Nigerian online retail industry.

(d) Explore the influence of privacy on customer satisfaction in the Nigerian online retail industry.

\section{REVIEW OF RELATED LITERATURE}

\section{E-commerce}

Basically, e-commerce is in the industrial economy to a "knowledge economy in transition to developed countries led to new enterprises as the main driving force, arising from an industrial structure, enterprise structure changes. November 6, 1997 in Paris of France at the World ecommerce conference that "e-commerce refers to the realization of electronic trade (Rahman \& Han, 2011). from the coverage area can be defined as: parties to the transaction by electronic means rather than through direct face to face exchange or conducted interviews of any form of commercial transactions; from the technical aspects can be defined as: a collection of multitechnology, including the exchange of data (such as electronic data, e-mail), access to data (shared databases, electronic bulletin boards), and automatically capture Data (bar codes), etc.. "Although this definition of the most authoritative, but so far, people's understanding of ecommerce still has not been uniform (in Rahman \& Han, 2011).

As electronic-commerce (e-commerce) grows and further exploits the attributes of the Internet, it will likely have significant effects on national economies and industry structure. E-commerce has come to take on two important roles; first as a more effective and efficient conduit and aggregator of information, and second, as a potential mechanism for the replacement of many economic activities once performed within a business enterprise by those that can be done by outside suppliers that compete with each other to execute these activities. In response to this increased level of outsourcing opportunities, businesses will exploit the benefits of e-commerce by decoupling as many links of their production chain as possible in order to seek the most efficient and low-cost supplier within the e-marketplace. Given as the Internet has a global reach, these new e-marketplaces have fast become a product of globalization, leading the Internet and e-commerce to further the process of global integration. In its most basic form, e-commerce is any transaction made over the Internet. Most often this involves the transfer of goods, services, or information.

The Internet is only the latest stage in advances in information and communication technologies (ICTs) that have progressively made information more accessible, faster to gather, less expensive to consume, and easier to analyse effectively. Due to the generally low cost of the technology that makes access to the Internet possible, it is more universally affordable than other previous electronic means of communication or information technology (Rahman \& Han, 2011). While 
using electronic means to communicate and exchange goods and services (i.e. bulletin board systems e-mail) is not new, today's e-commerce model is more effective because it exploits the best qualities of the Internet. The Internet's ubiquity, interactivity, ability to integrate data platforms and distribute intelligence allows e-commerce to discover new markets and consumers, foster economic specialization and increase productivity. In this regard then, e-commerce only accelerates the trend toward globalization, integration and specialization that has been underway for many years.

Although the presentation on the above definitions vary, but it is not difficult to discover the common that e-commerce is "information technology and "business combination. It is not a purely technical concept and a simple business concept, but modern information technology and the combination of modern business techniques, "e" just means, "business" is fundamental.

\section{Customer Satisfaction}

The definition of customer satisfaction has been widely debated as organizations increasingly attempt to measure it. Customer satisfaction can be experienced in variety of situations and connected to both goods and services. It is a highly personal assessment that is greatly affected by customer expectations. Satisfaction also is based on the customer's experience of both contact with the organization (the - moment of truth $\|$ as it is called in business literature) and personal outcomes. Some researchers define a satisfied customer within the private sector as -one who receives significant added valuell to his/her bottom line — a definition that may apply just as well to public services.

Customer satisfaction is a collective outcome of perception, evaluation, and psychological reactions to the consumption experience with a product or service. According to Kottler (2000) - satisfaction is a person's feelings of pleasure or disappointment resulting from comparing a product perceived performance or outcome in relation to his or her expectations. Early concept of satisfaction research has typically defined satisfaction as a post choice evaluation judgment concerning a specific purchase decision (Oliver, 1980). Yang Fang, (2004) believes that online customers still demand many services available through traditional channels even if they choose pure Internet-based suppliers with basic customer services. Although expectations seem to be of lesser importance as a comparison standard in e-commerce (Zeithaml et al., 2000), customers appear to use experience-based norms (Cadotte et al., 1987) and traditional services as comparison standards for e-services (Van Riel et al., 2001). Establishing and achieving customer satisfaction is the main goal of businesses nowadays because there is a strong relationship between the quality of product, customer satisfaction and profitability.

These surveys provide - actionablell data that reveal obvious steps for improvement. Customer satisfaction is a highly personal assessment that is greatly influenced by individual expectations. Some definitions are based on the observation that customer satisfaction or dissatisfaction results from either the confirmation or disconfirmation of individual.

To avoid difficulties stemming from the kaleidoscope of customer expectations and differences, some experts urge companies to - concentrate on a goal that's more closely linked to customer equity. Instead of asking whether customers are satisfied, they encourage companies to determine how customers hold them accountable. In the public sector, the definition of customer satisfaction is often linked to both the personal interaction with the service provider and the outcomes experienced by service users. For example, the Urban Institute and Mathematical conducted 
customer satisfaction surveys for the federal child support enforcement system. Kotler posits that satisfaction is a person through a product or service on the perceived effect compared with the expected value of his feeling after the formation of the state. Arussell also believes that the actual results achieved when the goods when consumers are expected to lead to a satisfactory, or else it will lead to customer dissatisfaction.

The degree to customer expectations of a product or service are met or exceeded. Corporate and individual customers may have widely differing reasons for purchasing a product or service and therefore any measurement of satisfaction will need to be able to take into account such differences. The quality of after-sales service can also be a crucial factor in influencing any purchasing decision. More and more companies are striving, not just for customer satisfaction, but for customer delight, that extra bit of added value that may lead to increased customer loyalty. Any extra added value, however, will need to be carefully cost.

\section{Service Performance}

Satisfaction is as an attitude-like judgment following a consumption experience. Most research confirms that the confirmation or disconfirmation of pre-consumption expectations is the essential determinant of satisfaction (Wirtz \& Mattila, 2001). This means that customers have a certain predicted service level in mind prior to consumption. This predicted level typically is the outcome of the search and choice process, when customers decided to buy a particular service. During the service encounter, customers experience the service performance and compare it to their predicted service levels. Satisfaction judgments are then formed based on this comparison. The resulting judgment is labeled positive disconfirmation if the service is better than expected, negative disconfirmation if it is worse than expected, and simple confirmation if it is as expected (Oliver, 1997).In short, customers evaluate service performance by comparing what they expected with what they perceive they received from a particular supplier.

Customers will be reasonably satisfied as long as perceived performance falls within the zone of tolerance, that is, above the adequate service level. As performance perceptions approach or exceed desired levels, customers will be very pleased; these customers are more likely to make repeat purchases, remain loyal to that supplier, and spread positive word of mouth. However, if the service experience does not meet their expectations, customers may complain about poor service quality, suffer in silence, or switch providers in the future (Ganesh, Arnold \& Reynolds, 2000).In highly competitive service markets, customers may expect service providers to even anticipate their unexpressed needs and deliver on them (Karmarkar, 2004).

\section{Formulation of Hypotheses}

The following hypotheses are formulated to guide the study and they are stated in alternate forms:

H1: System efficiency has significant influence on consumer satisfaction among online shoppers.

H2: System availability has significant influence on consumer satisfaction among online shoppers

H3: Fulfilment has significant influence on consumer satisfaction among online shoppers.

H4: Privacy has significant influence on consumer satisfaction among online shoppers. 


\section{METHODOLOGY}

Quantitative research design was adopted and used in this study. Quantitative research design places heavy emphasis on using formalized questions and pre-determined response options in questionnaire administered to large numbers of respondents (Hair, Bush \& Ortinau 2006). The population of this study comprises the active online shoppers in Anambra state. Identifying who is an online shopper or who shops online is the major limitation. Accurate trends and record of online shoppers in Nigeria are still lacking; as there are no catalogue of what can be referred to online shoppers' list. Thus, this study has an infinite population and the sample size determination will follow the statistical method for determining samples from such population. Because the population of this study is an unknown population, a pilot survey was conducted among 30 active online shoppers in Awka, Onitsha and Nnewi (with 10 respondents from each city) and the questions asked related to whether they have shopped online, and their knowledge of online shopping. Of this only 30 or $75 \%$ agreed that they shop online and are aware of online shops, while 10 or $25 \%$ answered to the negative or were indifferent. With this information the sample size for this study was obtained using the Top rank formula:

$$
\mathrm{n} \quad=\quad \frac{\mathrm{Z}^{2} \times \mathrm{P} \times \mathrm{Q}}{\mathrm{e}^{2}}
$$

where: $\mathrm{Z}=$ standard normal deviation which at .01 level is 1.96 .

$\mathrm{P}=$ the proportion of success and from the pilot study is 0.75

$\mathrm{Q}=$ the proportion of failure which is 0.25 ; and

$\mathrm{e}=$ the error margin which is assumed to be $5 \%$ or 0.05

Therefore: $\mathrm{n}=\frac{1.96^{2} \times .75 \times .25}{0.05^{2}}=288.12$

Hence the sample size for the study is approximated to 288 respondents. The sampling procedure adopted for this study is the quota sampling method. This study adopted questionnaire as the research instrument. It consisted of two sections, namely section A- demographic variables and section B- the core questions. The variables used in this study are five and these are: impulse purchase- 3 items; brand orientation- 2 items; shopping orientation- 2; purchase experience- 3 items; online trust- 7 items and three demographic variables which include gender, age, and education. All the variables and their respective items were measured using five point Likert scale of: strongly agree, agree, undecided, disagree, and strongly disagree and this is in line with researches in marketing and consumer behaviour.To ensure the validity of the questionnaire to be used in this research, attempts was made to ensure that the measurement reflects and represents the various aspects of the phenomenon/variables and issues in online shopping behaviour of consumers. This is to ensure face and content validity. Factor Analysis was employed to check reliability analysis with respect to internal consistency and the multidimensional attributes. The data collected were analysed with tables and percentages and other descriptive statistics like mean and standard deviations. Factor Analysis was also used to test the reliability of the instrument to ensure consistency with respect to the individual variables/items in the research instrument. Pearson Product Moment Correlations was used to check discriminant validity and collinearity. Again, Factor analysis was used to reduce the items while multiple regression analysis will be used to test the hypotheses to confirm their acceptability or otherwise. The 
questionnaire was pre-coded for ease of analysis; and data was analyzed with the aid of the computer software, Statistical Package for Social Sciences (SPSS) 23.

\section{ANALYSIS AND RESULT}

A total of 200 copies of questionnaire were distributed to online shoppers in Anambra State, out of which 182 were returned as duly filled and usable. This represents a response rate of $91 \%$ which very high and was informed by the fact that the researcher took time off to distribute the questionnaire himself in the various towns selected for the study. The demographic variables used in the study are follows: gender, educational qualification, and age bracket. The responses to these demographic variables confirmed that the data merit analysis as the responses have reasonable education and are equally of reasonable age to give valid information for the study. The respondents cut across the different gender. The detailed responses are show in table one below.

Table 4.1: Demographic Characteristics of the Respondents

\begin{tabular}{|c|c|c|c|c|c|}
\hline & & Frequency & Percent & Valid Percent & $\begin{array}{l}\text { Cumulative } \\
\text { Percent }\end{array}$ \\
\hline \multirow{3}{*}{ Gender } & Male & 92 & 50.6 & 50.6 & 50.6 \\
\hline & Female & 90 & 49.4 & 49.4 & 100.0 \\
\hline & Total & 182 & 100.0 & 100.0 & \\
\hline \multirow{5}{*}{$\begin{array}{l}\text { Age } \\
\text { bracket: }\end{array}$} & below 30 years & 91 & 50.0 & 50.0 & 50.0 \\
\hline & $30-39$ years & 60 & 33.0 & 33.0 & 83.0 \\
\hline & $40-49$ years & 27 & 15.0 & 98.0 & 98.0 \\
\hline & 50 years and above & 4 & 2.0 & 2.8 & 100.0 \\
\hline & Total & 182 & 100.0 & 100.0 & \\
\hline \multirow{5}{*}{ Educationa } & O’Level & 2 & 1.0 & 1.0 & 1.0 \\
\hline & $\mathrm{ND} / \mathrm{NCE}$ & 34 & 18.8 & 18.8 & 19.8 \\
\hline & HND/BSc & 137 & 75.0 & 75.0 & 94.8 \\
\hline & Postgraduate & 9 & 5.2 & 5.2 & 100.0 \\
\hline & Total & 182 & 100.0 & 100.0 & \\
\hline
\end{tabular}

Source: Field Survey, 2020

\section{Validity Analysis}

A correlation matrix was constructed using the constructs in the questionnaire to show the strength of relationship among the variables considered in the questionnaire and to check for collinearity among the constructs. The results of the Pearson product moment correlation analysis are shown in Table 4.2. 
Print ISSN: 2053-4019(Print), Online ISSN: 2053-4027(Online)

Table 4.2: Correlations Matrix.

\begin{tabular}{|l|r|r|r|r|c|}
\hline Variables & Efficiency & Availability & Fulfilment & Privacy & $\begin{array}{c}\text { Customer } \\
\text { Satisfaction }\end{array}$ \\
\hline Efficiency & 1 & & & & \\
Availability & $.374(* *)$ & 1 & & & \\
Fulfilment & $.395(* *)$ & $.254(* *)$ & 1 & & \\
Privacy & $.276(* *)$ & $.267(* *)$ & $.478(* *)$ & 1 & \\
Customer & $.647(* *)$ & $.721(* *)$ & $.743(* *)$ & $.637(* *)$ & 1 \\
satisfaction & & & & 1 \\
\hline
\end{tabular}

** Correlation is significant at the 0.01 level (2-tailed).

\section{Source: SPSS file, 2020}

As shown in Table 4, the correlation matrix indicates all the correlation between the independent variables: Efficiency; Availability; Fulfilment; and Privacy are well below the 0.70 threshold indicating absence of collinearity among the variables. By rule of thumb, high correlation of 0.6 and above between independent variables is a problem as it indicates that the two variables are doing the job; while high correlation of 0.6 between dependent and independent variable is good as it shows relationship. From Table 4.2 we that the correlations between the dependent and independent variables are above 0.6 which is acceptable as it shows there is a relationship between the variables. These correlations are also evidence of validity of the constructs used in the measurement scales used in this research.

\section{Reliability Analysis}

Factor analysis was conducted to check the reliability of the e-service performance dimensions; and the method was principal component extraction method of the factor analysis. The factor analysis was conducted and run separately for each of the five constructs, that is four independent variables and on dependent variable. The summary is given below while the details are in appendix 3. Thus, we summarize the Kaiser-Meyer-Olkin (KMO); the Bartlett's Test of Sphericity; the mean responses, the communalities, eigenvalue; percent of variance; and the reliability coefficients.

Table 4.3: Kaiser-Meyer-Olkin and the Bartlett's Test of Sphericity

\begin{tabular}{|l|c|c|c|}
\hline \multirow{2}{*}{ Variables } & $\begin{array}{c}\text { Kaiser-Meyer- } \\
\text { Olkin } \\
\text { Values }\end{array}$ & \multicolumn{2}{c|}{ Bartlett's Test of Sphericity } \\
\cline { 3 - 4 } & & $\begin{array}{c}\text { Approx. Chi-Square } \\
\text { value }\end{array}$ & Sig. \\
\hline Efficiency & 0.717 & 619.276 & 0.000 \\
Availability & 0.611 & 74.193 & 0.000 \\
Fulfilment & 0.552 & 190.060 & 0.000 \\
Privacy & 0.571 & 41.699 & 0.000 \\
Customer & 0.660 & 182.892 & 0.000 \\
satisfaction & & & \\
\hline
\end{tabular}

\section{Source: SPSS File,2020}

These dimensions were five constructs listed under e-service quality namely Efficiency ( 8 items), Availability (4 items), Fulfilment (7 items), Privacy (3 items), and the dependent variable Customer satisfaction (5 items). The KMO measure of sampling adequacy value for the 
constructs indicate sufficient inter correlations as all the correlations are above the 0.5 threshold. The Bartlett's Test of Sphericity was also found to be highly statistically significant at 0.000 which is well below the .05 margin of error.

Table 4.4: Mean, Standard Deviation and Factor analysis of the study constructs

\begin{tabular}{|c|c|c|c|c|c|c|}
\hline $\begin{array}{l}\text { Construct and } \\
\text { item }\end{array}$ & Mean & $\begin{array}{l}\text { Standard } \\
\text { Deviation }\end{array}$ & $\begin{array}{l}\text { Factor } \\
\text { loadings }\end{array}$ & Eigenvalue & $\begin{array}{l}\text { \% of } \\
\text { Variance }\end{array}$ & Reliability \\
\hline Efficiency & & & & 3.406 & 42.571 & 0.72 \\
\hline Eff1 & 1.77 & .722 & .342 & & & \\
\hline Eff2 & 2.27 & .970 & .694 & & & \\
\hline Eff3 & 2.29 & .967 & .635 & & & \\
\hline Eff4 & 2.59 & 1.112 & .686 & & & \\
\hline Eff5 & 2.30 & .904 & .416 & & & \\
\hline Eff6 & 2.10 & .919 & .562 & & & \\
\hline Eff7 & 2.03 & .997 & .596 & & & \\
\hline Eff8 & 2.07 & .984 & .671 & & & \\
\hline Availability & & & & 1.682 & 42.050 & 0.77 \\
\hline Ava1 & 2.47 & 1.001 & .222 & & & \\
\hline Ava2 & 2.41 & .986 & .483 & & & \\
\hline Ava3 & 2.50 & 1.012 & .519 & & & \\
\hline Ava4 & 2.85 & 1.130 & .458 & & & \\
\hline Fulfilment & & & & 1.994 & 28.491 & 0.75 \\
\hline Ful1 & 2.68 & 1.018 & .750 & & & \\
\hline Ful2 & 2.86 & 1.160 & .740 & & & \\
\hline Ful3 & 2.04 & .897 & .344 & & & \\
\hline Ful4 & 2.09 & .865 & .793 & & & \\
\hline Ful5 & 2.36 & .891 & .598 & & & \\
\hline Ful6 & 2.18 & .844 & .696 & & & \\
\hline Ful7 & 2.31 & 1.059 & .494 & & & \\
\hline Privacy & & & & 1.484 & 49.454 & 0.83 \\
\hline Pri1 & 2.51 & 1.001 & .532 & & & \\
\hline Pri2 & 3.49 & 1.136 & .345 & & & \\
\hline Pri3 & 2.03 & 1.205 & .607 & & & \\
\hline Customer & & & & 2.135 & 42.693 & 0.81 \\
\hline Satisfaction & & & & & & \\
\hline $\mathrm{CS} 1$ & 2.91 & 1.039 & .691 & & & \\
\hline $\mathrm{CS} 2$ & 2.66 & 1.356 & .340 & & & \\
\hline $\mathrm{CS} 3$ & 2.23 & 1.110 & .381 & & & \\
\hline CS4 & 2.15 & .688 & .516 & & & \\
\hline CS5 & 2.51 & .974 & .207 & & & \\
\hline
\end{tabular}

Source: SPSS File, 2020

Table 4.4 Also from the table all the items have mean above 1.50 and up to 2.50 while most of the standard deviation values are above one. Standard deviations measure variability hence with standard deviations above one is an indication that the respondents are opinions are diverse. Next on the Table is the factor loadings. Some of the construct items like Efficiency 1, Availability 1, Fulfilment 3, and Privacy 2. Customer satisfaction 2, 3, and 5 loaded below the 0.4 cut-off point 
used in the Factor analysis hence were deleted in the subsequent analysis. The next is the Eigenvalues for the constructs which all have values above 1 indicating that the constructs are reliable. The next is the $\%$ of variance explained which is within acceptable range. Finally, the

Table 4.5: Regression Model Summary ${ }^{b}$

\begin{tabular}{lr|r|r|r|r}
\hline Model & R & R Square & \multicolumn{1}{c}{$\begin{array}{c}\text { Adjusted R } \\
\text { Square }\end{array}$} & $\begin{array}{l}\text { Std. Error of } \\
\text { the Estimate }\end{array}$ & Durbin-Watson \\
\hline 1 & $.767^{\mathrm{a}}$ & .588 & .575 & .65195333 & 1.595 \\
\hline
\end{tabular}

a. Predictors: (Constant), Efficiency, Availability, Fulfilment, Privacy.

b. Dependent Variable: Customer Satisfaction

Reliability coefficients and all the constructs have reliability coefficients of above the 0.6 threshold and this is an indication that the scale and the constructs are reliable hence we proceed to regression analysis and hypotheses testing.

\section{Hypotheses Testing}

The statistical software used for the data analysis was SPSS for Windows Version 25.0. The multiple regression analysis was used to further explain the relationship between the independent and dependent variables. The statistical significance or margin of error targeted was .05 alpha levels which is typical in most research (Cooper \& Schindler, 2006; Sekaran, 2000). Multiple regression analysis was employed to test the hypotheses.

The first output from the multiple regression analysis is Model Summary and from this we see that Multiple $\mathrm{R}$ that is coefficient of multiple correlation is 0.767 which is a high correlation. The coefficient of determination $\mathrm{R}^{2}$ is 0.588 while the Adjusted $\mathrm{R}^{2}$ which takes care of error in the model is 0.575 . This means that between $57.5 \%$ and $76.7 \%$ of variations in customer satisfaction towards online shopping are accounted for by the 4 independent variables. The next information is the ANOVA.

\section{Table 4.6: Regression ANOVA ${ }^{\mathrm{a}}$}

\begin{tabular}{ll|r|r|r|r|r}
\hline Model & & $\begin{array}{c}\text { Sum of } \\
\text { Squares }\end{array}$ & df & Mean Square & \multicolumn{1}{c}{ F } & \multicolumn{1}{c}{ Sig. } \\
\hline 1 & Regression & 138.090 & 4 & 34.523 & 61.648 & $.000^{\mathrm{b}}$ \\
\cline { 2 - 7 } & Residual & 96.910 & 173 & .560 & & \\
\cline { 2 - 8 } & Total & 235.000 & 181 & & & \\
\hline
\end{tabular}

a. Dependent Variable: Customer satisfaction

b. Predictors: (Constant), Efficiency, Availability, Fulfilment, Privacy.

ANOVA as part regression output provides the statistical test for the overall model fit in terms of the $F$ ratio (Hair, Black, Babin \& Anderson, 2010). Tabachinick and Fidell (2013) state that the overall inferential test in multiple regressions is whether the sample of scores is drawn from a population in which multiple $R$ is zero. This is equivalent to the null hypothesis that all correlations between dependent variable (DV) and independent variables (IVs) are zero. For this analysis our $F$ ratio is 61.648 which is significant at .000 hence the null hypothesis that Multiple $R$ and the coefficients are zero is rejected. Based on this we proceed to interpret the coefficients and use them to validate the hypotheses. 
Table 4.7: Regression Coefficients ${ }^{\mathrm{a}}$

\begin{tabular}{|c|c|c|c|c|c|c|c|}
\hline \multirow[b]{2}{*}{ Model } & \multicolumn{2}{|c|}{$\begin{array}{l}\text { Unstandardized } \\
\text { Coefficients }\end{array}$} & \multirow{2}{*}{$\begin{array}{c}\text { Standardi } \\
\text { zed } \\
\text { Coefficie } \\
\text { nts } \\
\text { Beta } \\
\end{array}$} & \multirow[b]{2}{*}{$\mathbf{T}$} & \multirow[b]{2}{*}{ Sig. } & \multicolumn{2}{|c|}{$\begin{array}{l}\text { Collinearity } \\
\text { Statistics } \\
\text { Toleran }\end{array}$} \\
\hline & & $\begin{array}{l}\text { Std. } \\
\text { Error }\end{array}$ & & & & $\begin{array}{c}\text { Toleran } \\
\text { ce }\end{array}$ & VIF \\
\hline (Constant) & 1.412 & .420 & & 3.362 & .000 & & \\
\hline Efficiency & .619 & .059 & .619 & 10.445 & .000 & .515 & 1.942 \\
\hline Availability & .124 & .051 & .124 & 2.407 & .017 & .684 & 1.462 \\
\hline Fulfilment & .212 & .058 & .212 & 3.675 & .000 & .542 & 1.846 \\
\hline Privacy & .206 & .060 & .206 & 3.424 & .001 & .498 & 2.007 \\
\hline
\end{tabular}

a. Dependent Variable: Customer Satisfaction

From the table of the regression coefficients, Efficiency has a coefficient has $(\beta=0.619, \mathrm{t}=10.445$, $\rho=.000$ ) and based on this Hypothesis One which states that: Efficiency positively and significantly relates to customer satisfaction in online shopping is fully validated and accepted. Availability has a coefficient has $(\beta=0.124, \mathrm{t}=2.407, \rho=.017)$, based on this, Hypothesis Two which states that: Availability positively and significantly relates to customer satisfaction in online shopping is fully validated and accepted. Fulfilment has a coefficient has $(\beta=0.212$, $\mathrm{t}=3.675, \rho=.000$ ), based on this Hypothesis Three which states that: Fulfilment positively and significantly relates to customer loyalty in online shopping is fully validated and accepted. Privacy has a coefficient has $(\beta=0.206, \mathrm{t}=3.424, \rho=.001)$ and based on this Hypothesis Four which states that: Privacy positively and significantly relates to customer satisfaction in online shopping is fully validated and accepted.

\section{DISCUSSION}

The study was based on four dimensions of the electronic service performance dimensions: system efficiency, system availability, fulfilment and privacy developed by Parasuraman, Zeithaml, and Malhotra, (2005). The independent variable is the customer satisfaction among online shoppers in Anambra State. E-service performance can play a critical role in improving the services quality delivered to its customers as it can achieve survival, increase satisfaction and trust and then generate the competitive success for organizations (Feindt et al. 2002). Customer perceived e-service performance is one of the critical determinants of the success of online business (Yang et al. 2004). Accordingly, there is a rise of research on the construct of e-service performance. The aim of this study is to assess E-service performance and customer satisfaction among online shoppers in an online service setting. The findings indicate that a combination of the four dimensions relating to system efficiency, system availability, fulfilment and privacy represents the measurement of e-service performance within the online shopping context in Anambra State, Nigeria. According to the survey results of the customers satisafction, "efficiency" was rated as the most significant e-Service performance (SP) dimension. This dimension was followed in ranking by fulfilment, privacy and availability. A comparison with previous surveys of customers' views reveals that reliability was reported by Zeithaml (2002) to be the most important dimension in all services. Similarly, Wolfinbarger and Gilly (2003), who examined consumers' perceptions of online retailers, found that "reliability" was the strongest 
predictor of e-SP. Reliability was not employed in this study. Our findings however are in agreement with Parasuraman, et al. (2005). Results of this study indicated that E-service quality was directly associated with customer satisfaction among online shoppers. Findings provided evidence that E- service performance dimensions were influential on customer satisfaction to online outlets.

\section{CONCLUSIONS}

The rapid diffusion of ICT in the Nigerian banking sector provides a platform to use innovative technologies to enhance operational efficiency and quality of service to attract and retain customers. This has brought about new methods of distributing goods and services to attract and retain customers. E-service can play a crucial role in enhancing the services quality delivered to its customers as it can achieve growth and survival, increase satisfaction and trust and then generate the competitive success for businesses. The four dimensions of the E-service performance employed in this study are system efficiency, System availability, system fulfilment and privacy. Analysis of the data show that all the four dimensions are significant in enhancing and bringing about customer loyalty in online setting. Accordingly, Management needs to view and think from a customer's perspective so that it is helpful for management to meet or exceed its service quality to customers' expectations and by doing so bring about loyalty in online settings and transactions.

\section{Implications}

The findings from this study may be helpful for practitioners to better understand the sources of customer loyalty in online shopping environments as it relates to e-Service performance. The management of online shopping outlets needs to view and think from customers' perspectives so that the management understands customers' expectations as well as those factors that enhance satisfaction. It was hypothesized in this study that E- service performance was determined by four major dimensions: System Efficiency, System availability, Fulfilment and Privacy. The findings of the study show that all these four variables are significant in influencing customer loyalty in an online environment. Marketing practitioners require frameworks and models that enable them to better understand their consumers in the internet environment. Thus, the model in this study offers practitioners "a clear picture" and a useful tool to better understand their consumers, why they are attracted to the e-service, and how they react within the business to consumer internet environment. Thus, practitioners need to consider these factors in ensuring the quality of a content driven e-service. Obviously in order to provide a high level of overall service quality, online retailing management and decision makers should pay attention to all of the four dimensions which were identified in this study. So, to improve e-SP, the priorities of managers need to be harmonized with customers' perceptions.

\section{References}

Achumba, I.C. (2006). The Dynamics of Consumer Behaviour. Lagos: Mc-Williams Publishers. Adjei, K. \& Denanyoh, R. (2014). Determinants of customer Loyalty among telecom subscribers in the Brong Ahafo Region of Ghana", International Journal of Business and Social Research (IJBSR) 4(1), 82-95.

Angelides, M.C. (1997). Implementing the Internet for business: a global marketing opportunity”, International Journal of Information Management, 17 [6],405-419. 
Arnould, E; Price, L; \&Zinkhan, G. (2004).Consumers. Irvin: McGraw Hill.

Ayo CK, Ekong OU, Fatudimu IT, Adebiyi AA (2007). M-Commerce Implementation in Nigeria: Trends and Issues. J. Internet Bank. Commer., 12(2):1-15.

Basu, A. \& Muylle, S. (2003), "Online support for commerce processes by web retailers", Decision Support Systems , 34 [4], pp. 379-395.

Bednarz A 2002 Working out the kinks in the retail supply chain. NetworkWorld October: 36,http://www.networkworld.com/research/2002/0610feat.html.

Bellenger, D.N. \& Korgaonkar, P.K. (1980), "Profiling the recreational shopper", Journal of Retailing, Vol. 56 No. 3, pp. 77-92.

Brown, M., Pope, N. \& Voges, K. (2001), "Buying or browsing? An exploration of shopping orientations and online purchase intention", European Journal of Marketing, Vol. 37 No. 11, pp. 1666-84.

Burke, R. R. (1997) "Do you see what I see: the future of virtual shopping", Journal of the Academy of Marketing Science, 25 (4), 352-360.

Cadotte, E. R., Woodruff, R.B., \& Jenkins, R.L., (1987). "Expectations and norms in models of consumer satisfaction". Journal of Marketing Research. 24(3) 305-314.

Ceccucci, W., Peslak, A. \& Sendall, P. (2010), "An empirical study of behavioural factors influencing text messaging intention", Journal of Information Technology Management, Vol. XXI No. 1, pp. 16-34.

Chen, M. Chang, K. Hsu, C. \& Yang, I. (2010). Understanding the Relationship between Service Convenience and Customer Satisfaction in Home Delivery by Kano Model. Asia Pacific Journal of Marketing and Logistics 23(3) 386-410 Emerald Group Publishing Limited

Chang; C. M. K., Chan; G. W. W. \& Limayem, M. (2005) "A Critical Review of Online Consumer Behaviour: Empirical Research", Journal of Electronic Commerce in Organizations; 3 [4], pp. 1-19.

Cockburn, C. \& Wilson, T. D (1996) "Business Use of the World-wide Web", International Journal of Information Management, 16 (2), pp. 83-102.

Coye, R. W. (2004). "Managing Customer Expectations in the Service Encounter," International Journal of Service Industry Management, 15 (4), 54-71.

Davis FD, Bagozzi R P. \& Warshaw P (1989). User Acceptance of Computer Technology: A Comparison of Two Theoretical Models. Manage. Sci., 35: 982-1003

Dishaw, M.T. \& Strong, D.M. (1999) "Extending the technology acceptance model with tasktechnology fit constructs".Information \& Management, 36 (1), 9-21.

Doherty, N.F., \& Ellis-Chadwick, F.E. (2009), "Exploring the Drivers, Scope and Perceived Success of ecommerce Strategies in the UK Retail Sector", European Journal of Marketing, 43 [9/10], pp 1246-1262.

Donthu, N. \& Garcia, A. (1999), "The internet shopper”, Journal of Advertising Research, Vol. 39 No. 3, pp. 52-8.

Egger, A. (2006), "Intangibility and perceived risk in online environments", Journal of Marketing

Ellis-Chadwick, F.E., Doherty, N.F. \& Hart, C.A. (2002), "'Signs of Change? A Longitudinal Study of Internet Adoption in the UK Retail Sector", Journal of Retailing and Consumer Services, Vol. 9 No.2, pp 71-80.

Evanschitzky, H., Gopalkrishnan, R., Hesse, J. \& Dieter, A. (2004), "E-satisfaction: a reexamination", Journal of Retailing, Vol. 80, pp. 239-247.

Fornell, C; VanAmburg, D; Morgeson, F; Anderson, E.W.; Bryant, B.E; \& Johnson, M.D. (2005). The American Customer Satisfaction Index at Ten Years-A Summary of Findings: Implications for the Economy, Stock Returns and Management. Ann 
Arbor, MI: National Quality Research Center, University of Michigan, 54.

Gan C; Clemes, M; Limsombunchai V; \&Weng A (2006). A Logit Analysis of Electronic Banking in New Zealand. Discussion paper No. 108.

Ganesh, J.; Arnold, M.J. \& Reynolds, K.E. (2000). "Understanding the Customer Base of Service Providers: An Examination of the Differences between Switchers and Slayers," Journal of Marketing, 64 (3), 65-87.

Gattiker, U.E. (1990), Technology Management in Organizations, Sage, Newbury Park, CA.

Gehrt, K.C., Onzo, N., Fujita, K. \& Rajan, N.R. (2007), "The emergence of internet shopping in Japan: identification of shopping orientation-defined segment", Journal of Marketing Theory and Practice, Vol. 15 No. 2, pp. 167-77.

Hair, J.F; Bush, R.P. \& Ortinau, D.J. (2006).Marketing Research. New York: McGraw Hill/Irwin.

Hamel G, \& Sampler J 1998 The e-corporation. Fortune 7(Dec.): 80.

Hamner, M. \& Qazi, R.-u.-R. (2009), "Expanding the technology acceptance model to examine personal computing technology utilization in government agencies in developing countries", Government Information Quarterly, Vol. 26 No. 1, pp. 128-136.

Ho, S. C., Kauffman, R. J., \& Liang, T. P. (2007) "A Growth Theory Perspective on B2C ecommerce Growth in Europe: An Exploratory Study." Electronic Commerce Research and Applications, 2007, 6, pp. 237-259.

Howcroft, B; Hamilton, R; \& Hewer, P. (2007) "Customer Involvement and Interaction in Retail Banking: An Examination of Risk and Confidence in the Purchase of financial products" Journal of services Marketing: 21/7 481-491 Emerald Publishing www.emeraldinsight.com/0887-6045.htm.

Ilie, V., Van Slyke, C., Green, G. \& Lou, H. (2005), "Gender difference in perception and use of communication technologies: a diffusion of innovation approach", Information Resources Management Journal, Vol. 18 No. 3, pp. 13-31.

Jayawardhena, C., Wright, L.T. \& Dennis, C. (2007), "Consumer online: intentions, orientations and segmentation", International Journal of Retail \& Distribution Management, Vol. 35 No. 6, pp. 515-26.

Kalakota R. \& Robinson M (1999). e-Business: Roadmap for success (Reading, MA: Addison Wesley)

Karmarkar, U. (2004). "Will You Survive the Service Revolution?" Harvard Business Review, June 2004, 101-108.

Khurshid, M. (2013), 'Determinants of Customer Loyalty, its causes and influence in Telecom Industry: A study of Mobile Telecom Industry in Pakistan" International Review of Social Sciences.

King, W.R. \& He, J. (2006), “A meta-analysis of the technology acceptance model”, Information \& Management, 43 (6),740-755.

Kleindi \& Burrow (2005), E-commerce Marketing. Thomson South-Western.

Kotler, P \& Keller, K.L (2016), Marketing Management 15 (ed), New Jersey: Prentice Hall. Online Edition.

Kuo, Y. \& Yen, S. (2009), "Towards an understanding of the behavioural intention to use 3G mobile value-added services", Computers in Human Behaviour, 25(1), 103-110.

Kuo, Y. \& Yen, S. (2009), "Towards an understanding of the behavioural intention to use 3G mobile value-added services", Computers in Human Behaviour, 25 (1), 103-110. 
Laroche, M., Yang, Z., McDougall, G.H.G. \& Bergeron, J. (2005), "Internet versus bricks- and mortar retailers: an investigation into intangibility and its consequences", Journal of Retailing, 81 (4), 251-67.

Legris, P., Ingham, J. \& Colerette, P. (2003), "Why do people use information technology? A critical review of the technology acceptance model", Information and Management,40, 191-204.

Levenburg, N. (2005), "Delivering Customer Value Online: Analysis of Practices, Applications and Performance", Journal of Retailing and Consumer Services, 12 (5), 319-331.

Li, H., Kuo, C. \& Russell, M.G. (1999), "The impact of perceived channel utilities, shopping orientations and demographics on the consumer's online buying behaviour", Journal of Computer-Mediated Communication. 5 (2), available at: http://onlinelibrary.wiley. com.

Ling, K.C., Chai, L.T. \& Piew, T.H. (2010), "The effects of shopping orientations, online trust and prior online purchase experience toward customers' online purchase intention", International Business Research, 3 (3), 63-76.

Lopez-Nicolas, C., Molina-Castillo, F. and Bouwman, H. (2008), "An assessment of advanced mobile services acceptance: contributions from TAM and diffusion theory models", Information \& Management. 45, 359-364.

Lovelock, C. \&Wirtz, J. (2011). Services Marketing: People, Technology, Strategy. Upper Saddle River, New Jersey: Pearson Education Inc.

Luo, X. (2002). "Uses and Gratifications Theory and E-Consumer Behaviours: A Structural Equation Modelling Study" Journal of Interactive Advertising.

Mafe', C.R., Blas, S.S. \& Tavera-Mesı'as, J.F. (2010), “A comparative study of mobile messaging services acceptance to participate in television programmes", Journal of Service Management, Vol. 21 No. 1, pp. 69-102.

McCole, P. \& Palmer, A. (2001), "A critical evaluation of the role of trust in direct marketing over the internet", Proceedings of the American Marketing Society World Marketing Congress, Cardiff, Wales, CD-ROM, 28 June.

Nath, R., Akmanligil, M., Hjelm, K., Sakaguchi, T., \& Schultz, M. (1998). "Electronic commerce and the Internet: issues, problems, and perspectives". International Journal of Information Management, 18 [2], pp. 91-101.

Oinas, P. (2002). Towards understanding network relationships in online retailing. Int. Rev. Retail, Distrib. Consumer Res. 12(3): 319-335.

Oliver, R.L., (1980) "A cognitive model of the antecedents and consequences of satisfaction decisions" Journal of Marketing Research, Vol. XVII, November

Oliver, R. L. (1997). Satisfaction: A Behavioural Perspective on the Consumer, New York: McGraw-Hill, 1997.

Oliver, R.L; Rust, R.T. \& Varki, S. (1997). “Customer Delight: Foundations, Findings, and Managerial Insight," Journal of Retailing, 73, Fall, 311-336.

Otto, J.R. \& Chung, Q.B. (2000). A framework for cyber-enhanced retailing: Integrating ecommerce retailing with brick-and-mortar retailing. Electronic Markets 10(3): 185-191

Pan S L, \& Lee J.N. (2003). Using e-CRM for a unified view of the customer. Communication. ACM 46(4): 95-99

Papadopoulou, P., Andreou, A., kanellis, P. \& Martakos, D. (2001). Trust and relationship building in electronic commerce. Internet Research: Electronic Networking and Policy, 11 (4), 322-332. 
Peterson, R. A., Balasubranian, S. \& Bronnenberg, B. J. (1997), "Exploring the implications of the Internet for consumer marketing", Journal of the Academy of Marketing Science, 25 (4), pp. 329-346.

Piron, F. (1991), "Defining impulse purchasing", in Holman, R. and Solomon, M. (Eds), Advances in Consumer Research, Vol. 18, Association for Consumer Research, Provo, UT, pp. 509-14.

Preissl, B. (2002). E-Commerce in the European retail sector. European Retail Digest, (36): 8285

Premkumar, G. \& Ramamurthy, K. (1995). "The role of inter-organizational and organizational factors on the decision mode for adoption of inter-organizational systems", Decision Sciences, Vol. 26 No. 3, pp. 303-336.

Pura, M. (2005), "Linking perceived value and loyalty in location-based mobile services", Managing Service Quality, Vol. 15 No. 6, pp. 509-538.

Rahman, H \& Han, H. (2011). Customer satisfaction in E-Commerce: A case study of China and Bangladesh. Master's Thesis in International Business 15 ECTS Department of Economics and Informatics University West

Rahman, H. \& Han, L. (2011). Customer Satisfaction in E-Commerce: A case study of China and Bangladesh. Master's Thesis. Department of Economics and Informatics. University West.

Rayport, J.F. \& Sviokla, J.J. (1994) "Managing in the marketspace". Harvard Business Review; 72, pp. 141-50.

Roadcap, C.A., Smith, P. M., \& Michael, J.H. (2002). Internet technologies in the home center industry. Forest Products Journal. 52(1): 32-37.

Rogers, E.M. (1983), Diffusion of Innovations, Free Press, New York, NY.

Rogers, E.M. (1983), Diffusion of Innovations, Free Press, New York, NY.

Rook, D.W. (1987), “The buying impulse”, Journal of Consumer Research, Vol. 14 No. 2, pp. 189-1999.

Rust, R.T.; \& Oliver, R.L (2000) "Should We Delight the Customer?" Journal of the Academy of Marketing Science, 28 (1), 86-94.

Shim, S. \& Drake, M.F. (1990), "Consumer intention to utilize electronic shopping”, Journal of Direct Marketing, Vol. 4 No. 2, pp. 22-33.

Shim, S., Gehrt, K.C. \& Lotz, S.L. (2001), "Export implications for the Japanese fruit market: fruit-specific lifestyle segments", International Journal of Retail \& Distribution Management, Vol. 29 No. 6, pp. 300-16.

Shin, D.-H. (2007), "User acceptance of mobile internet: implication for convergence technologies", Interacting with Computers, Vol. 19 No. 4, pp. 472-483.

Slyke, C.V. (2002), "Gender differences in perceptions of web-based shopping", Communications of the ACM, Vol. 47 No. 7, pp. 82-6.

Srinivasan, S., Anderson, R., \& Kishore, P. (2002), "Customer Loyalty in e-commerce: an Exploration of its Antecedents and Consequences", Journal of Retailing, 78 [1], pp. 4150.

Swaminathan, V., Lepkowska-White, E. \& Rao, B.P. (1999) "Browsers or buyers in cyberspace? An investigation of factors influencing electronic exchange" Journal of ComputerMediated Communication, 5 [2], pp. 1-19.

Teo, T.S.H. \& Liu, J. (2007), "Consumer trust in e-commerce in the United States, Singapore and China”, Omega, Vol. 35 No. 1, pp. 22-8. 
Tirschwell, P. M. (2004). Demanding. Exacting. Uncompromising: Retailers raise the bar on logistics performance. J. Commerce 5(3): 14-17

Van Riel, A.C.R., Liljander, V. \& Jurriens, P. (2001) "Exploring consumer evaluations of eservices: a portal site", International Journal of Service Industry Management, 12 (4), 359-377.

Venkatesh, V. \& Bala, H. (2008), "Technology acceptance model 3 and a research agenda on interventions", Decision Sciences, Vol. 39 No. 2, pp. 273-315.

Vijayasarathy, L.R. \& Jones, J.M. (2000), "Intentions to shop using internet catalogues: exploring the effect of the product types, shopping orientations and attitudes toward computers", Electronic Market, 10 (1), 29-38.

Ward, M.R. \& Lee, M.T. (2000), "Internet shopping, consumer search and product branding", Journal of Product \& Brand Management, Vol. 9 No. 1, pp. 6-21.

Wirtz, J. \& Mattila, A. S. (2001) "Exploring the Role of Alternative Perceived Performance Measures and Needs-Congruency in the Consumer Satisfaction Process," Journal of Consumer Psychology, 11(3), 181-192.

Wirtz, J. (2003). "Halo in Customer Satisfaction Measures - the Role of Purpose of Rating, Number of Attributes, and Customer Involvement," International Journal of Service Industry Management, 14 (1), 96-119.

Wolfinbarger, M. \& Gilly, M (2003) "etailQ: Dimensionalizing, Measuring and Predicting etail Quality”, Journal of Retailing, Vol.79, No.3, pp.183-198.

Yang, Z., \& Fang, Z, (2004). Online services quality dimension and their relationships with satisfaction a content analysis of customer reviews of securities brokerage services. The International Journal of Bank marketing, 15(3), 189-206.

Zhu K, \& Kraemer, K. L. (2002). e-Commerce metrics for net-enhanced organizations: Assessing the value of e-commerce to firm performance in the manufacturing sector. Inf. Syst. Res. 13(3): 275-295.

Zhuang Y., Lederer, A. L. (2003). An instrument for measuring the business benefits of ecommerce retailing. International Journal of Electronic Commerce 7(3): 65-99.

Zeithaml, V.A., Parasuraman, A. \& Malhotra, A. (2000): A Conceptual Framework for Understanding e-Service Quality: Implications for Future Research and Managerial Practice: Working paper, Cambridge MA, Marketing Science Institute, Report Number 00-115. 